justyna.sendecka@p.lodz.pl

Maciej Sierpowski

maciej.sierpowski@p.lodz.pl

Biblioteka Politechniki Łódzkiej

\title{
WIEDZA, KOMPETENCJE, ZAANGAŻOWANIE - WARTOŚCI DETERMINUJĄCE ROZWÓJ BIBLIOTEKARZA
}

\begin{abstract}
Responsibilities of the librarian, especially in the science library, are constantly changing, so the librarians need to improve their education and participate in training all the time. The librarian should be a specialist in books acquisition and cataloging as well as an expert in the obtaining, selecting and disseminating of information. In this article the authors try, on the example of the Library of the Lodz University of Technology, to give an answer to a number of questions: how should librarians career path proceed? What impact has an activity of a librarian on the promotion taking into consideration the latest changes in librarian education? And what impact have regulations governing the professional status of librarians? What is more important: education or skills of employees? What criteria are to be adopted to assess, reward and motivate the library staff to a more efficient and creative work? What educational and professional skills of the employees are particularly important for the proper functioning of the library?
\end{abstract}

Słowa kluczowe: rozwój zawodowy bibliotekarzy, umiejętności bibliotekarzy, szkolenia zawodowe w bibliotece

\section{Wstęp}

Biblioteka w tradycyjnym rozumieniu jest instytucją kultury, a więc instytucją społeczną, której główną rolą jest udostępnianie zgromadzonych, przechowywanych (archiwizowanych) i uporządkowanych materiałów bibliotecznych zarówno w wersji drukowanej, jak i cyfrowej. Zajmuje się również promowaniem dziedzictwa kulturowego i dorobku naukowego oraz przygotowaniem użytkowników do samodzielnego poszukiwania i selekcjonowania informacji. Obecnie udostępnianie własnej kolekcji zbiorów drukowanych ustępuje miejsca organizowaniu dostępu do informacji. Wszystkie biblioteki gromadzą informację (wiedzę) w formie książek, czasopism, zbiorów specjalnych, ale coraz większe znaczenie ma udostępnianie zasobów w formie cyfrowej.

Biblioteki pełnią kilka podstawowych funkcji: informacyjną, edukacyjną, wspierania kształcenia, intelektualną, rozrywkową i estetyczną ${ }^{1}$.

\footnotetext{
${ }^{1}$ J. Wojciechowski, Biblioteka w komunikacji publicznej, Warszawa 2010, s. 149-186.
} 
Dodatkowo misją bibliotek akademickich (naukowych), których dotyczy artykuł, jest wspieranie działalności dydaktycznej i naukowo-badawczej uczelni przez zapewnianie dostępu do materiałów bibliotecznych i zasobów informacyjnych niezbędnych do prowadzenia prac naukowo-badawczych i dydaktyki ${ }^{2}$. Polskie biblioteki akademickie działają na podstawie Ustawy o bibliotekach ${ }^{3}$ oraz ustawy Prawo o szkolnictwie wyższym ${ }^{4}$, zgodnie z którą w uczelniach funkcjonuje system biblioteczno-informacyjny, którego podstawę stanowi biblioteka. System ten tworzą najczęściej: biblioteka główna, biblioteki wydziałowe, instytutowe, zakładowe, a jego zadaniem jest zaspokajanie potrzeb naukowych i dydaktycznych studentów i pracowników uczelni. Warto podkreślić, że biblioteka składa się z wielu powiązanych ze sobą elementów. Na jej pracę mają między innymi wpływ użytkownicy oraz ich potrzeby, jak i środowisko społeczne, w jakim funkcjonuje. Nowoczesna biblioteka to taka, która łączy w sobie przestrzeń rzeczywistą i wirtualną. Coraz częściej wskazuje się także na kulturotwórczą rolę bibliotek akademickich (szczególnie w uczelniach technicznych), będących miejscem spotkań, gdzie użytkownicy nie tylko mogą zdobywać i wymieniać się informacją, ale także uczestniczyć w wydarzeniach o charakterze rozrywkowym i zaspokajać swoje potrzeby estetyczne.

Od początku lat dziewięćdziesiątych biblioteki naukowe w Polsce i na świecie przeszły liczne zmiany na wszystkich polach swojej działalności. Skutecznie wykorzystały rozwój technologii, aby unowocześnić i zautomatyzować swoje usługi. Nowoczesne technologie umożliwiły wprowadzenie bardzo korzystnych dla użytkowników zmian w procesie zarządzania informacją, które zapewniły między innymi bezpośredni dostęp do zasobów elektronicznych i pełnotekstowych baz danych. Od kilku lat tworzone są także centra wiedzy, w których udostępniany jest zasób kilku bibliotek naukowych. Rozwój i unowocześnienie bibliotek został przyśpieszony dzięki rozwojowi Internetu, co umożliwiło rozpowszechnianie informacji w skali światowej ${ }^{5}$.

Wraz z innymi bibliotekami naukowymi również Biblioteka Politechniki Łódzkiej (BPŁ) wdrożyła zintegrowany system biblioteczny, dzięki któremu zautomatyzowano podstawowe procesy biblioteczne: gromadzenie, opracowanie i udostępnianie zbiorów. Nastąpiło przejście na elektroniczny system wypożyczania zbiorów, udostępniono elektroniczne katalogi z możliwością zamawiania egzemplarzy książek. Rozwinięto także ofertę biblioteki, poszerzając ją o elektroniczne źródła informacji i oferując pomoc w dotarciu do literatury światowej. Zmiany wprowadzili bibliotekarze, jednak by zrobić to profesjonalnie, na bieżąco musieli uzupełniać swoją wiedzę.

\footnotetext{
${ }^{2}$ Ustawa z dnia 27 czerwca 1997 r. o bibliotekach, [dostęp:12.04.2015], http://isap.sejm. gov.pl/DetailsServlet?id=WDU19970850539.

${ }^{3}$ Ibidem.

${ }^{4}$ Ustawa z dnia 27 lipca 2005 r. Prawo o szkolnictwie wyższym, [dostęp:12.04.2015], http://isap.sejm.gov.pl/DetailsServlet?id=WDU20051641365.

${ }^{5}$ Bibliotekarstwo, red. A. Tokarska, Warszawa 2014, s. 22-24.
} 
Innowacje w bibliotekach to nie tylko automatyzacja czy zmiana oferty. Wiele bibliotek, w tym również BPŁ reorganizuje struktury organizacyjne, żeby lepiej dostosować się do oczekiwań czytelników. Tę sytuację doskonale ilustruje Oddział Obsługi Użytkowników, który powstał z połączenia Oddziału Udostępniania Zbiorów, Oddziału Informacji Naukowej i Oddziału Wydawnictw Ciągłych, którego celem jest zapewnienie kompleksowej pomocy czytelnikom, bez zbędnego odsyłania do innych agend. Bibliotekarze przyjęli na siebie nowe obowiązki i stanęli przed faktem uczenia się przez całe życie (Life Long Learning ${ }^{6}$ ).

BPŁ stale poszerza ofertę dostępu do komercyjnych źródeł informacji naukowej oraz promuje zasoby Internetu. Praca z użytkownikiem polega na wskazaniu najlepszych dla niego źródeł, wyszukaniu relewantnych informacji oraz pomocy w wyselekcjonowaniu najwartościowszej literatury.

Kolejny obszar zmian to reorganizacja przestrzeni bibliotecznej. Wiele bibliotek, w tym BPŁ, utworzyła wolny dostęp do zbiorów, jednocześnie likwidując magazyny, niedostępne wcześniej dla czytelnika. Ponadto stworzyła biblioteczną galerię, w której promowana jest twórczość pracowników i studentów uczelni, a także regionalnych artystów. Rozpoczęto również promocję twórczości literackiej miasta i regionu w formie spotkań w „Przedsionku Literackim”, które prowadzone są przez bibliotekarzy.

\section{Kompetencje bibliotekarzy a uregulowania prawne}

Mirosława Majewska wskazuje grupy kompetencji, które powinien mieć bibliotekarz, jednocześnie podkreślając, że zaproponowany katalog nie wyczerpuje listy umiejętności:

- $\quad$ kompetencje prakseologiczne - skuteczność bibliotekarza w planowaniu, organizowaniu, realizacji, kontroli i oceny procesów bibliotecznoinformacyjnych;

- $\quad$ kompetencje komunikacyjne - skuteczność zachowań językowych w relacjach bibliotekarz - użytkownik;

- $\quad$ kompetencje współdziałania - skuteczność zachowań prospołecznych i sprawność integracyjna bibliotekarza w środowisku społecznym, umiejętność pracy w zespole;

- $\quad$ kompetencje kreatywne - innowacyjność, niestandardowość działań bibliotekarza;

- $\quad$ kompetencje informatyczne - sprawność w korzystaniu z nowoczesnych technologii informacyjnych i medialnych ${ }^{7}$.

\footnotetext{
${ }^{6}$ Por. M. Stąporek, J. Radzicka, Internet jako narzędzie wspomagajace i aktywizujace bibliotekarzy, [w:] IV Forum Młodych Bibliotekarzy, Kraków 2009, s. 5, [dostęp: 12.04.2015], http://eprints.rclis.org/17360/3/St\%C4\%85porek_Radzicka_Internet $\% 20 \mathrm{a} \% 20$ samokszta $\%$ C5\% 82cenie_IV\%20forum\%20m\%C5\%82odych\%20bibliotekarzy.pdf.

${ }^{7} \bar{M}$. Majewska, Kompetencje bibliotekarza wobec zmian społecznych i edukacyjnych, [dostęp 06.05.2015], http://e-pedagogiczna.edu.pl/upload/file/dokumenty/jarocin6.pdf.
} 
Ocena kompetencji pracownika zdaniem autorów artykułu powinna mieć decydujący wpływ na ścieżkę awansu zawodowego, obok obligatoryjnych, formalnych wymagań ujętych $\mathrm{w}$ przepisach. W przypadku bibliotek naukowych podstawy przyznawania awansów są ściśle określone przez ustawodawcę. Na stanowiska niższego rzędu, na przykład magazyniera, nie wymagany jest staż pracy czy wykształcenie bibliotekarskie, na stanowisku młodszego bibliotekarza mogą być zatrudnione osoby z wykształceniem wyższym bez stażu lub z wykształceniem średnim bibliotekarskim oraz rocznym stażem ${ }^{8}$. Aby piastować stanowisko bibliotekarza należy posiadać wykształcenie wyższe i trzy lata stażu pracy lub wykształcenie średnie bibliotekarskie (sześć lat stażu), inne średnie (osiem lat stażu). W przypadku awansu na stanowisko starszego bibliotekarza potrzebne są ukończone studia wyższe oraz sześcioletni staż pracy w bibliotece naukowej. Natomiast najwyższe stanowisko kustosza wiąże się koniecznością posiadania dyplomu ukończenia wyższych studiów magisterskich oraz dziesięcioletniego stażu pracy w bibliotece naukowej ${ }^{9}$.

Uregulowania te stanowią podstawę do przyznawania awansów i są przejrzyste dla pracowników, jednak staż pracy i zdobyte przed laty wykształcenie to nie wszystko. Uzupełnianie wiedzy specjalistycznej z dziedziny bibliotekoznawstwa i informacji naukowej jest bardzo ważne. Ponadto bibliotekarz powinien wyróżniać się umiejętnością pracy z użytkownikiem: przekazania informacji, przeszkolenia użytkownika $\mathrm{w}$ zakresie samodzielnego wyszukiwania i selekcjonowania informacji. Wymaga to wiedzy interdyscyplinarnej, również z zakresu pedagogiki, psychologii czy informatyki.

Ukoronowaniem kariery i tytułem bardzo prestiżowym dla bibliotekarza jest stanowisko bibliotekarza dyplomowanego. O tym, że warto stworzyć takie stanowisko zaczęto dyskutować już na początku 1958 r. Ostatecznie pierwsze zasady egzaminów określone zostały w Rozporzadzeniu Ministra Szkolnictwa Wyższego, Zdrowia i Opieki Społecznej, Oświaty, Spraw Zagranicznych oraz Przewodniczacego Gtównego Komitetu Kultury Fizycznej i Turystyki z dnia 25 maja 1961 r. w sprawie warunków, jakim powinni odpowiadać kandydaci na bibliotekarzy dyplomowanych $w$ szkołach wyższych, oraz $w$ sprawie zasad $i$ trybu sktadania egzaminów bibliotekarskich ${ }^{10}$. Kolejne przepisy modyfikowały status i sposób zdobycia tytułu bibliotekarza dyplomowanego ${ }^{11}$.

\footnotetext{
${ }^{8}$ Warto nadmienić, że od lat nie funkcjonuje już system kształcenia bibliotekarzy na poziomie średnim.

${ }^{9}$ Rozporządzenie Ministra Nauki i Szkolnictwa Wyższego z dnia 11 grudnia 2013 r. w sprawie warunków wynagradzania za pracę i przyznawania innych świadczeń związanych z pracą dla pracowników zatrudnionych w uczelni publicznej, [dostęp: 11.04.2015], http:// www.nauka.gov.pl/finansowanie-akt/rozporzadzenie-ministra-nauki-i-szkolnictwa-wyzszego-zdnia-11-grudnia-2013-r-w-sprawie-warunkow-wynagradzania-za-prace-i-przyznawania-innychswiadczen-zwiazanych-z-praca-dla-pracownikow-zatrudnionych-w-uczelni-publicznej.html.

${ }^{10}$ Rozporządzenie Ministrów Szkolnictwa Wyższego, Zdrowia i Opieki Społecznej, Oświaty, Spraw Zagranicznych oraz Przewodniczacego Głównego Komitetu Kultury Fizycznej i Turystyki z dnia 25 maja 1961 r. w sprawie warunków, jakim powinni odpowiadać kandydaci na
} 
Do czasu wejścia w życie Ustawy z dnia 13 czerwca 2013 r. o zmianie ustaw regulujacych wykonywanie niektórych zawodów, dotyczącej deregulacji zawodów, warunki jakie należało spełnić, aby otrzymać status bibliotekarza dyplomowanego były jasno i dokładnie określone. Kandydatem na dyplomowanego bibliotekarza i dyplomowanego pracownika dokumentacji i informacji naukowej mogła być osoba mająca:

- $\quad$ tytuł magistra, magistra inżyniera lub równorzędny;

- co najmniej dwuletni staż pracy w bibliotece naukowej, ośrodku informacji naukowej, archiwum lub muzeum albo na stanowiskach nauczyciela akademickiego;

- udokumentowany dorobek działalności organizacyjnej i pracy dydaktycznej;

- $\quad$ co najmniej 2 publikacje z zakresu bibliotekoznawstwa, informacji naukowej, archiwistyki lub muzealnictwa w wydawnictwach recenzowanych oraz

- $\quad$ legitymująca się znajomością co najmniej jednego języka obcego, potwierdzoną przez komisję powołaną przez rektora lub dyplomem albo certyfikatem wydanym przez uprawnioną instytucję;

- $\quad$ skierowana do postępowania kwalifikacyjnego, przez dyrektora biblioteki, ośrodka informacji naukowej, archiwum lub muzeum.

Postępowanie kwalifikacyjne obejmowało ocenę dorobku naukowego i zawodowego kandydata na podstawie przedstawionej dokumentacji, w tym publikacji. Pozytywna recenzja dorobku naukowego umożliwiała zdawanie państwowego egzaminu składającego się z dwóch części - ogólnej i specjalistycznej. Ponadto $\mathrm{w}$ postępowaniu kwalifikacyjnym należało przedstawić: wniosek kierownictwa instytucji zatrudniającej kandydata o rozpoczęcie postępowania kwalifikacyjnego, opinię kierownictwa jednostki zatrudniającej kandydata o jego osiągnięciach zawodowych i dydaktycznych, a także życiorys oraz informację o przebiegu pracy zawodowej.

Ustawa z dnia 13 czerwca 2013 r. o zmianie ustaw regulujacych wykonywanie niektórych zawodów dotyczaca deregulacji zawodów ${ }^{12}$, która miała ułatwić dostęp do wybranych zawodów zlikwidowała jasne kryteria awansów, także na stanowisko bibliotekarza dyplomowanego. Ustawodawca uchylił obowiązujące dotychczas przepisy, odpowiedzialność powierzył uczelniom, co spowodowało zahamowanie w przyznawaniu awansów na stanowisko bibliotekarza dyplomowanego.

bibliotekarzy dyplomowanych $w$ szkołach wyższych, oraz w sprawie zasad i trybu sktadania egzaminów bibliotekarskich, [dostęp: 06.05.2015], http://isap.sejm.gov.p1/DetailsServlet?id=WDU 19610290143.

${ }^{11}$ Dyplomowany.pl, [dostęp: 12.04.2015], http://dyplomowany.pl/.

${ }^{12}$ Ustawa z dnia 13 czerwca 2013 r. o zmianie ustaw regulujacych wykonywanie niektórych zawodów, [dostęp: 28.09.2014], http://isap.sejm.gov.pl/DetailsServlet?id=WDU2013000 0829. 
Sprawą zainteresowała się Konferencja Dyrektorów Bibliotek Akademickich Szkół Polskich (KDBASP), a powołany przez nią zespół roboczy przygotował ujednolicone wymagania, jakie należałoby stawiać przed kandydatami na dyplomowanych bibliotekarzy i dyplomowanych pracowników dokumentacji i informacji naukowej. Wytyczne opracowane przez zespół zostały przekazane 25 kwietnia 2013 r. Konferencji Rektorów Akademickich Szkół Polskich ${ }^{13}$. Wymagania podzielono na cztery grupy: formalne (wykształcenie, znajomość języka obcego, minimalny staż pracy w bibliotece naukowej i liczba publikacji recenzowanych), dotyczące działalności naukowo-badawczej (pozostałe publikacje, udział w pracach komitetów i rad programowych, inne formy aktywności), związane $\mathrm{z}$ działalnością dydaktyczną (dydaktyka w różnych formach kształcenia, w tym zdalnych), związane $\mathrm{z}$ działalnością organizacyjną (pełnienie funkcji kierowniczych, udział w zespołach problemowych, działania o charakterze innowacyjnym, organizacja konferencji, szkoleń, praktyk). Konferencja Rektorów Akademickich Szkół Polskich rekomendowała uczelniom umieszczenie w statutach wymagań dla kandydatów na bibliotekarzy dyplomowanych. Jednym z proponowanych rozwiązań zapisanych w uchwale byłoby przyjęcie zasad rekomendowanych przez Konferencję Dyrektorów Bibliotek Akademickich Szkół Polskich ${ }^{14}$. Wiele uczelni nie wprowadziło jeszcze zmian w statutach, a w innych ze względu na lokalne interpretacje i intencje nie ujednolicily one wymagań stawianych kandydatom na bibliotekarzy dyplomowanych. Brak jasnych kryteriów, w wielu przypadkach zniechęcił potencjalnych kandydatów do starań o zdobycie statusu bibliotekarza dyplomowanego.

Warto nadmienić, że przyznanie regulacji uczelniom z dużym prawdopodobieństwem spowoduje, że na jednych uczelniach stanowisko to będzie łatwiej osiągalne niż na innych. Przykładem mogą być uczelnie państwowe z Lublina. Senaty trzech uczelni podjęły przed 1 października 2014 r. uchwały określające wymagania kwalifikacyjne oraz zasady awansowania dyplomowanych bibliotekarzy i dyplomowanych pracowników dokumentacji i informacji naukowej. Zapisy zawarte w statutach uczelni lubelskich w różny sposób regulują zasady odnoszące się do tej grupy bibliotekarzy. Pomimo wspólnego porozumienia zawartego w uchwale KRASP, rozwiązania przyjmowane przez poszczególne uczelnie są odmienne. Bez zmian rekomendację KRASP przyjęto w Katolickim Uniwersytecie Lubelskim Jana Pawła II, natomiast w Uniwersytecie Medycznym i Politechnice Lubelskiej bardziej ogólnie określono

${ }^{13}$ Wymagania dla kandydatów na dyplomowanych bibliotekarzy oraz dyplomowanych pracowników dokumentacji i informacji naukowej: rekomendacja Konferencji Dyrektorów Bibliotek Akademickich Szkót Polskich, [dostęp: 28.09.2014], http://kangur.uek.krakow.pl/kdbasp/ wp-content/upload s/2013/11/opinia_2013_03_25.pdf.

${ }^{14}$ E. Matczuk, A. Śniechowska-Karpińska, Status bibliotekarzy dyplomowanych w bibliotekach państwowych szkót wyższych Lublina - stan z października 2014 r., „Biuletyn EBIB” 2014, nr 8, [dostęp: 15.03.2015], http://open.ebib.pl/ojs/index.php/ebib/article/ view/284/461. 
wymagania dla kandydatów na dyplomowanych bibliotekarzy. Ze względu na różnice wynikające $\mathrm{z}$ wymagań, stanowisko bibliotekarza dyplomowanego w konkretnej uczelni obowiązuje tylko w tym miejscu pracy, co w znaczący sposób obniża jego prestiż.

\section{Wiedza i zaangażowanie $w$ pracę}

Na sposób przyznawania awansów i motywowania pracowników powinien wpływać zdaniem autorów rodzaj wykonywanej pracy i stopień trudności realizowanych obowiązków. Wykształcenie bibliotekarskie, jak już wcześniej podkreślono, jest bardzo ważne, stanowi podstawę pracy i pomaga $\mathrm{w}$ codziennym wypełnianiu zadań wynikających z podstawowych procesów bibliotecznych. Jednak nowe zadania współczesnych bibliotekarzy sprawiają, że wykształcenie zdobyte przed laty nie wystarcza, by być uwzględnionym w systemie motywowania i awansowania. Potrzebne jest nie tylko ugruntowanie posiadanej wiedzy, ale także uzupełnianie kwalifikacji. Nowa rzeczywistość wymaga podnoszenia swoich kwalifikacji, dokształcania się zarówno w ramach studiów podyplomowych, jak i szkoleń wewnętrznych i zewnętrznych, a także pracy własnej. Rozwój zawodowy bibliotekarza powinien być odpowiedzią na potrzeby użytkowników i zadania, jakie stawia przed nim codzienna praca.

Każdy z pracowników biblioteki ma określone umiejętności, kwalifikacje, wiedzę, energię, w różny sposób angażuje się w pracę i w tym kontekście ważne jest, aby przydzielone mu stanowisko pozwalało wykorzystać jego kompetencje z korzyścią dla biblioteki i jednocześnie zaspokajało potrzeby pracownika.

Kompetentny bibliotekarz powinien przede wszystkim być dobrze zorientowany w usługach jakie oferuje biblioteka, także w przestrzeni wirtualnej, musi też posiadać umiejętność obsługi sprzętu elektronicznego i oprogramowania, aby pomóc użytkownikowi.

Praca w bibliotece często jest związana z obsługą użytkowników. Pracownicy oprócz odpowiedniego wykształcenia, wiedzy merytorycznej powinni posiadać określone cechy osobowości. Trudno określić jednoznacznie kryteria, jakie winna spełniać osoba wykonująca zawód bibliotekarza, można jednak wyróżnić pewne umiejętności interpersonalne. Pracownik oprócz posiadanej wiedzy musi charakteryzować się otwartością, życzliwością, cierpliwością także w kontakcie $\mathrm{z}$ trudnymi czytelnikami i elastycznością ${ }^{15}$. Istotne jest również zaangażowanie $\mathrm{w}$ pracę.

Często predyspozycje i wiedza pracownika biblioteki decydują o jakości świadczonych usług, a tym samym o satysfakcji użytkownika, o pozytywnej ocenie biblioteki i wartości uzyskanych w niej informacji.

${ }^{15}$ G. Piotrowicz, Bibliotekarz a , użytkownik-klient” we wspótczesnej bibliotece uczelnianej, [dostęp 06.05.2015], http://ebib.wroc.pl/matkonf/torun/piotrowicz.php. 
Wizerunek nowoczesnej biblioteki, która odpowiada na różnorodne potrzeby użytkowników tworzony jest przez jej pracowników, ważne więc jest, aby byli oni odpowiednio wykwalifikowani i motywowani do systematycznego poszerzania swojej wiedzy i podnoszenia kwalifikacji.

W teorii zarządzania często zwraca się uwagę na zaangażowanie pracowników w wykonywaną pracę i podkreśla ogromne znaczenie takiej postawy, jednocześnie wskazując, że zaangażowanie często wynika bezpośrednio z umiejętności współdziałania pomiędzy pracownikami i motywującego wpływu przełożonego. Większość pracowników nie chce ograniczać się tylko do podpisywania listy obecności, chce widzieć w swojej pracy sens i czuć się potrzebnym $^{16}$. Ogromne znaczenie ma tutaj postawa przełożonych, docenienie jak ważni są pracownicy dla każdej instytucji, a więc i biblioteki, stanowi dla nich doskonałą motywacje i mobilizację do pracy. Reasumując, to pracownicy kształtują pozytywny wizerunek biblioteki, dbają o jej reputację i rozwój. Konieczne jest by wszyscy, niezależnie od zajmowanego stanowiska i posiadanych kwalifikacji czuli się potrzebni i sprawiedliwie traktowani, a także umieli współpracować między sobą w procesie kształtowania i świadczenia usług bibliotecznych $^{17}$.

Metody motywacyjne można podzielić na ekonomiczne i inne. Do materialnych środków motywowania pracowników biblioteki zaliczyć należy płace, premie, awans, nagrody. Jednak w związku z trudną sytuacją finansową większości bibliotek w Polsce oraz obowiązującymi biblioteki przepisami, korzystanie z materialnych środków motywowania pracowników bywa dość ograniczone. Dlatego dużego znaczenia nabierają pozamaterialne środki motywowania takie jak:

- zapewnienie pracownikom możliwości rozwoju, udziału w szkoleniach, rozwijania umiejętności;

- omawianie celów, których osiągnięcie powinno być priorytetem, zachęcanie do dyskusji nad możliwościami rozwiązania problemów i dawanie pracownikom pewnej swobody w wyborze sposobów realizacji powierzonych zadań;

- $\quad$ wyznaczanie pracownikom ciekawych i ambitnych zadań;

- $\quad$ wyrażanie uznania, chwalenie pracowników za ich osiągnięcia;

- $\quad$ zapewnianie sprawnej komunikacji, informowanie o ważnych dla instytucji wydarzeniach;

- $\quad$ zapewnienie dobrych warunków pracy, dostępu do nowoczesnych narzędzi;

- $\quad$ zapewnienie dobrej atmosfery i szacunku ${ }^{18}$. s. 34-63.

${ }^{16}$ M.W. Kopertyńska, Motywowanie pracowników. Teoria i praktyka, Warszawa 2008,

${ }^{17}$ L. Zbiegień-Maciąg, Marketing personalny, czyli jak zarzadzać pracownikami $w$ firmie, Warszawa 1996, s. 16.

${ }^{18}$ J. Kamińska, Motywowanie pracowników biblioteki, a koncepcja marketingu wewnętrznego, [dostęp: 5.04.2015], http://www.sbc.org.pl/dlibra/docmetadata?id=7679\&from =publication. 
Zaufanie pracowników do biblioteki oraz osób nią zarządzających jest niezbędnym, często brakującym ogniwem, które może zadecydować o sukcesie bądź jej porażce. Istotne jest by pracownicy mieli dostęp do pełnej informacji o zatrudniającej ich instytucji, widzieli sens wykonywanych przez siebie zadań i odczuwali satysfakcję z wykonywanej pracy. Na tą ostatnią wpływ ma bezpośrednie zaangażowanie w działalność instytucji, autentyczny udział w podejmowaniu decyzji dotyczących ich stanowiska pracy i wykonywanych zadań. Udział pracowników w podejmowaniu decyzji stanowi źródło zwiększenia satysfakcji i zadowolenia z pracy oraz motywacji do podnoszenia jakości pracy, rozwoju aktywności i innowacyjności pracowników biblioteki. Konieczne jest umożliwienie bibliotekarzom wyrażania myśli, zgłaszania pomysłów i propozycji, a do tego niezbędny jest sprawny system komunikacji wewnętrznej i sprzyjająca kultura organizacyjna.

Ważnym środkiem motywującym pracownika biblioteki może być pochwała jego pracy, podkreślanie osiągnięć dające poczucie podmiotowości, wpływające na poprawę samooceny i w rezultacie motywujące go do dobrej i efektywnej pracy. Duże znaczenie mają również jasne i przejrzyste zasady zarządzania, a także widoczne efekty pracy własnej. Motywować może też przyjazna atmosfera pracy, uznanie wśród współpracowników i możliwość sprawdzenia się $\mathrm{w}$ realizacji ambitnych zadań.

\section{Zarządzanie personelem w Bibliotece Politechniki Lódzkiej}

W 2012 r. w Bibliotece Politechniki Łódzkiej zlikwidowano magazyny zamknięte i otwarto bardziej przyjazną dla użytkowników przestrzeń wolnego dostępu, z której czytelnicy korzystają samodzielnie z fachowym wsparciem bibliotekarzy. Spowodowało to zmianę rodzaju pracy i zmusiło część personelu, która wcześniej pracowała w obszarach zamkniętych (magazynach) do podniesienia kwalifikacji i przejęcia części obowiązków, które dotąd pełnili pracownicy agendy informacyjnej. Udostępnienie zbiorów w otwartych przestrzeniach ujednoliciło w pewien sposób zakresy obowiązków, wywołując jednocześnie pytania: Czy można wymagać od pracowników o niższych kwalifikacjach pracy z czytelnikiem? Czy słuszne jest kierowanie ich na szkolenia podnoszące poziom wiedzy? Czy oni sami są gotowi i chętni do doskonalenia zawodowego? Czy mają predyspozycje do pracy z użytkownikiem? I jak w tej sytuacji powinien wyglądać system motywowania i awansowania?

W tym samym roku bibliotekarze wystąpili z propozycją wprowadzenia okresowej oceny wszystkich pracowników przez bezpośrednich przełożonych. Pomysł przewidywał także dodatkową ocenę kierowników agend przez pracowników i dyrekcji przez kierowników. Zgodnie z założeniem ocena pracowników i kierowników stanowiłaby dla dyrekcji podstawę do obiektywnego podejmowania decyzji związanych z awansowaniem i udzielaniem premii. Arkusze okresowej oceny kadry kierowniczej wypełnialiby anonimowo wszyscy pracownicy, podlegli kierownikowi oddziału. Dyrektor i zastępcy dyrektora 
podlegaliby ocenie kierowników oddziałów. Ocena okresowa mogłaby być istotnym kryterium przy nagradzaniu pracowników, a jednocześnie pozwoliłaby im zweryfikować własne umiejętności i jakość wykonywanej pracy. Propozycja oceny pracowników przewidywała: samoocenę, ocenę pracownika przez przełożonego i przez współpracowników. Wśród parametrów oceny pracowników zawarto: wiedzę i kwalifikacje odpowiadające stanowisku pracy, organizację czasu pracy i jego efektywne wykorzystanie, samodzielność, umiejętność pracy w zespole, zaangażowanie i dyscyplinę pracy. Ocena dokonywana byłaby w punktach, punkty przekładałyby się na skalę procentową, a skala procentowa na ocenę słowną. Otwarte pozostawało wciąż pytanie, czy ocena powinna być jawna, czy też powinien poznawać ją tylko zainteresowany. Pod dyskusję poddano również sposób powiązania oceny z procedurami awansowania i nagradzania pracowników. Prace i konsultacje nad opracowaniem arkuszy oceny nadal trwają, a bibliotekarze mimo pytań i wątpliwości przekonani są o słuszności wprowadzenia oceny ich pracy.

\section{Podsumowanie}

W pracy bibliotekarza najistotniejszą cechą jest umiejętność pracy z czytelnikiem. Obecnie dostęp do informacji można zdobyć w różnych rywalizujących ze sobą miejscach, a nade wszystko w świecie wirtualnym, co spowodowało, że użytkownicy stali się bardziej wymagający. Są świadomi swoich praw i większą wagę przywiązują do tego, w jaki sposób zostaną obsłużeni.

Warto podkreślić, że standardy obsługi użytkowników biblioteki nie mogą odbiegać od standardów w instytucjach komercyjnych. Najwyższy czas przestać myśleć i działać w kategoriach instytucji budżetowej, bo te również muszą się zmieniać. Bibliotekarze zwykli traktować osoby odwiedzające jako czytelników i nie należy zmieniać nomenklatury, niech nadal będą to czytelnicy, ale w domyśle powinni to być klienci. Czytelnik przychodząc do biblioteki spotyka przede wszystkim pracowników działu udostępniania, w przypadku Biblioteki Politechniki Łódzkiej bibliotekarzy z Oddziału Obsługi Użytkowników, do których obowiązków należy zarówno udostępnianie książek i czasopism w wersji tradycyjnej, jak i korzystanie z elektronicznych źródeł informacji.

Dlatego zdaniem autorów artykułu zdobyte wykształcenie i staż pracy powinny być tylko warunkiem koniecznym, ale niewystarczającym do otrzymania awansu. Podstawę nagradzania pracownika powinno stanowić jego zaangażowanie $\mathrm{w}$ pracę, podnoszenie kwalifikacji na szkoleniach czy w wyniku pracy własnej, a także umiejętność współpracy z czytelnikiem, cierpliwość i chęć pomocy. Bardzo ważne kryterium powinny stanowić efekty pracy bibliotekarza, gdyż nie wystarczy brać udział w szkoleniach - należy umieć wykorzystać zdobytą wiedzę w codziennej praktyce.

Wkład, jaki wnoszą bibliotekarze w działalność biblioteki, powinien znaleźć swoje odzwierciedlenie w wynagrodzeniu, a przede wszystkim w systemie motywacji i awansie zawodowym. Czas skończyć z awansowaniem jedynie 
w oparciu o wymogi formalne i pochylić się nad przydatnością określonych umiejętności i efektywnością bibliotekarzy. Czas również by przywrócić prestiż zawodu przez określenie zasad awansu na stanowisko bibliotekarza dyplomowanego, gdyż perspektywa osiągnięcia takiego awansu z pewnością podziała motywująco.

\section{Bibliografia}

Bibliotekarstwo, red. Z. Żmigrodzki, Warszawa 1998.

Bugom M., Zarządzanie zasobami ludzkimi w filozofii TQM, „Humanizacja Pracy” 1999, nr 1, s. 41-51.

Dyplomowany.pl, [dostęp:12.04.2015], http://dyplomowany.pl/.

Howorka B., Ustawa o bibliotekach-próba analizy, „Poradnik bibliotekarza”1997, nr 11, s. $6-8$.

Jaskowska B., O kompetencjach emocjonalnych $i$ społecznych $w$ działalności bibliotekarskiej, Między IQ a empatia - dobry bibliotekarz to jaki?, red. K. Zioło, Gliwice 2008.

Kamińska J., Motywowanie pracowników biblioteki a koncepcja marketingu wewnętrznego, [dostęp: 5.04.2015], http://www.sbc.org.pl/dlibra/docmetadata?id=7679\&from=publica tion.

Kopertyńska M.W., Motywowanie pracowników. Teoria i praktyka, Warszawa 2008.

Majewska M., Kompetencje bibliotekarza wobec zmian społecznych i edukacyjnych, [dostęp: 06.05.2015], http://e-pedagogiczna.edu.pl/upload/file/dokumenty/jarocin6.pdf.

Matczuk E., Śniechowska-Karpińska A., Status bibliotekarzy dyplomowanych $w$ bibliotekach państwowych szkót wyższych Lublina - stan z października 2014 roku, „Biuletyn EBIB” 2014, nr 8, [dostęp: 15.03.2015], http://open.ebib.pl/ojs/index.php/ebib/articleview/ 284/461.

Pietroń-Pyszczek A., Motywowanie pracowników. Wskazówki dla menadżerów, Wrocław 2007.

Piotrowicz G., Bibliotekarz a „użytkownik-klient” we współczesnej bibliotece uczelnianej, [dostęp: 06.05.2015], http://ebib.wroc.p1/matkonf/torun/piotrowicz.php.

Rozporządzenie Ministra Nauki i Szkolnictwa Wyższego z dnia 11 grudnia 2013 r. w sprawie warunków wynagradzania za pracę i przyznawania innych świadczeń zwiąanych z praca dla pracowników zatrudnionych $w$ uczelni publicznej, [dostęp: 11.04.2015], http:// www.nauka.gov.pl/finansowanie-akt/rozporzadzenie-ministra-nauki-i-szkolnictwa-wyzsze go-z-dnia-11-grudnia-2013-r-w-sprawie-warunkow-wynagradzania-za-prace-i-przyznawa nia-innych-swiadczen-zwiazanych-z-praca-dla-pracownikow-zatrudnionych-w-uczelnipublicznej.html.

Rozporzadzenie Ministra Nauki i Szkolnictwa Wyższego z dnia 21 sierpnia 2006 r. w sprawie kandydatów na dyplomowanego bibliotekarza oraz dyplomowanego pracownika dokumentacji i informacji naukowej, [dostęp: 06.05.2015],http://isap.sejm.gov.pl/DetailsServlet? id=WDU20061551112.

Rozporządzenie Ministrów Szkolnictwa Wyższego, Zdrowia i Opieki Spolecznej, Oświaty, Spraw Zagranicznych oraz Przewodniczacego Głównego Komitetu Kultury Fizycznej i Turystyki $z$ dnia 25 maja 1961 r. w sprawie warunków, jakim powinni odpowiadać kandydaci na bibliotekarzy dyplomowanych $w$ szkołach wyższych, oraz $w$ sprawie zasad i trybu sktadania egzaminów bibliotekarskich, [dostęp: 06.05.2015], http://isap.sejm.gov.pl/ DetailsServlet?id=WDU19610290143. 
Stąporek M., Radzicka J., Internet jako narzędzie wspomagające i aktywizujące bibliotekarzy, [w:] IV Forum Młodych Bibliotekarzy, Kraków 2009, s. 5, [dostęp: 12.04.2015], http:// eprints.rclis.org/17360/3/St\%C4\%85porek_Radzicka_Internet $\% 20 \mathrm{a} \% 20$ samokszta $\% \mathrm{C} 5 \%$ 82cenie_IV\%20forum $\% 20 \mathrm{~m} \% \mathrm{C} 5 \% 82$ odych\%20bibliotekarzy.pdf.

Ustawa z dnia 27 czerwca 1997 r. o bibliotekach, [dostęp: 12.04.2015], http://isap.sejm.gov.pl/ DetailsServlet?id=WDU19970850539.

Ustawa z dnia 27 lipca 2005 r. Prawo o szkolnictwie wyższym, [dostęp: 12.04.2015], http:// isap.sejm.gov.pl/DetailsServlet?id=WDU20051641365.

Wałek A., Pinkawa P., Bibliotekarz cyfrowy - specjalizacja z pogranicza dziedzin. Bibliotekarz: zawód czy powołanie, pod red. M. Geryka, Gdańsk 2010.

Wojciechowski J., Biblioteka w komunikacji publicznej, Warszawa 2010.

Wymagania dla kandydatów na dyplomowanych bibliotekarzy oraz dyplomowanych pracowników dokumentacji i informacji naukowej: rekomendacja Konferencji Dyrektorów Bibliotek Akademickich Szkót Polskich, [dostęp 28.09.2014], http://kangur.uek.krakow.pl/kdbasp/wp -content/uploads/2013/11/opinia_2013_03_25.pdf.

Zarzębski T., Z problemów nowoczesnej organizacji zbiorów bibliotecznych, „Przegląd Biblioteczny" 1997, nr 1, s. 201-209.

Zbiegień-Maciąg L., Marketing personalny, czyli jak zarzadzać pracownikami w firmie, Warszawa 1996. 